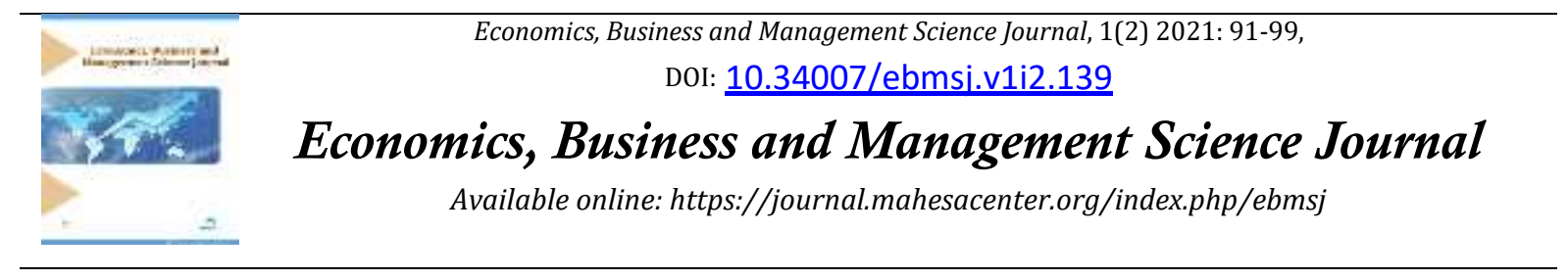

\title{
Pengaruh Kewajiban Kepemilikan NPWP, Pemeriksaan Pajak Dan Penagihan Pajak Terhadap Penerimaan Pajak Pada Kantor Pelayanan Pajak Pratama Bangkinang
}

\section{The Influence of the Obligation of Ownership of TIN, Tax Audit and Tax Collection on Tax Revenue at the Bangkinang Pratama Tax Service Office}

\author{
Masril \\ Sekolah Tinggi Ilmu Ekonomi Mahaputra Riau, Indonesia \\ Abstrak
}

\begin{abstract}
Tujuan penelitian ini adalah untuk mengetahui adakah pengaruh kewajiban kepemilikan NPWP terhadap penerimaan pajak pada Kantor Pelayanan Pajak Pratama Bangkinang, untuk adakah pengaruh pemeriksaan pajak terhadap penerimaan pajak pada Kantor Pelayanan Pajak Pratama Bangkinang, untuk mengetahui adakah pengaruh penagihan pajak terhadap penerimaan pajak pada Kantor Pelayanan Pajak Pratama Bangkinan, dan untuk mengetahui apakah kewajiban kepemilikan NPWP, pemeriksaan pajak dan penagihan pajak mempunyai pengaruh secara simultan terhadap penerimaan pajak pada Kantor Pelayanan Pratama Bangkinang.

Kata Kunci: Kewajiban Kepemilikan NPWP; Pemeriksaan Pajak; Penagihan Pajak; Penerimaan Pajak
\end{abstract}

\begin{abstract}
The purpose of this study was to determine whether there is an effect of NPWP ownership obligations on tax receipts at the Bangkinang Pratama Tax Service Office, to find out whether there is an effect of tax audits on tax receipts at the Bangkinang Pratama Tax Service Office, to determine whether there is an effect of tax collection on tax receipts at the Pratama Tax Service Office. Bangkinan, and to find out whether the NPWP ownership obligation, tax audit and tax collection have a simultaneous effect on tax revenues at the Bangkinang Primary Service Office. Keywords: TIN Ownership Obligation; Tax Audit; Tax Collection; Tax Receipt

How to Cite: Masril. (2021). Pengaruh Kewajiban Kepemilikan NPWP, Pemeriksaan Pajak Dan Penagihan Pajak Terhadap Penerimaan Pajak Pada Kantor Pelayanan Pajak Pratama Bangkinang. Economics, Business and Management Science Journal, 1(2) 2021: 91-99,
\end{abstract}


Masril, Pengaruh Kewajiban Kepemilikan NPWP, Pemeriksaan Pajak Dan Penagihan Pajak Terhadap

Penerimaan Pajak Pada Kantor Pelayanan Pajak Pratama Bangkinang

\section{PENDAHULUAN}

Sebagai negara yang berkembang, sebenarnya Indonesia memiliki berbagai macam potensi untuk menjadi negara yang lebih maju. Akan tetapi pada kenyataannya Indonesia tidak bisa memanfaatkan berbagai potensi itu. Bisa dilihat kenyataannya sekarang, di Indonesia mengalami berbagai masalah hampir di semua sektor yang ada, salah satu masalah terbesar adalah masalah di sektor ekonomi, untuk memperbaiki masalah tersebut maka pajak diharapkan bisa menjadi solusi yang efektif. Pada tahun 2008 pemerintah melalui Direktorat Jederal Pajak mengeluarkan kebijakan berupa sunset policy. (Tambunan, 2016; Kadir, 2018). Kebijakan sunset policy ini diharapkan dapat meningkatkan partisipasi dan kesadaran masyarakat dalam membayar pajak sehingga dana pajak yang dirasakan dapat lebih luas bagi kemakmuran dan kesejahteraan masyarakat. Dalam sunset policy, pemerintah secara tidak langsung mewajibkan masyarakat sebagai wajib pajak untuk memiliki Nomor Pokok Wajib Pajak (NPWP) (Fitriyani dan Wiwik, 2009).

Semua wajib pajak yang telah memenuhi persyaratan subjektif dan objektif sesuai dengan ketentuan peraturan perundang-undangan perpajakan berdasarkan sistem self assessment, wajib mendaftarkan diri pada kantor Direktorat Jenderal Pajak untuk dicatat sebagai wajib pajak dan sekaligus untuk mendapatkan NPWP. Persyaratan objektif adalah persyaratan bagi subjek pajak yang menerima atau memperoleh penghasilan atau yang diwajibkan untuk melakukan pemotongan/pemungutan sesuai dengan ketentuan Undang-Undang PPh 1984 dan perubahannya. (Dalimunthe \& Sembiring, 2020; Hidayat \& Irwan, 2013). Wajib pajak adalah orang pribadi atau badan, meliputi pembayar pajak, pemotong pajak dan pemungut pajak, yang mempunyai hak dan kewajiban perpajakan sesuai dengan ketentuan peraturan perundangundangan perpajakan (Casavera, 2009).

Pemberian Nomor Pokok Wajib Pajak (NPWP) kepada setiap wajib pajak disertai dengan pelaksanaan hak dan kewajiban perpajakan.Pengesahan pemberian NPWP dilakukan dengan pemberian Surat Keterangan Terdaftar.Surat tersebut menginformasikan pemenuhan kewajiban perpajakan kepada setiap wajib pajak.Berdasarkan hasil penelitian petugas Seksi Tata Usaha Perpajakan, kewajiban perpajakan tersebut diisi dan harus dilaksanakan oleh setiap wajib pajak.Pengisian kewajiban perpajakan harus didasarkan pada ketentuan peraturan perundangundangan perpajakan yang berlaku, sehingga pelaksanaan atas kewajiban perpajakan oleh setiap wajib pajak dapat mengamankan penerimaan pajak.Semakin banyak yang diisi kewajiban perpajakan oleh wajib pajak secara benar dan tepat, penerimaan pajak meningkat (Setiawan, 2007).

Dirjen pajak berupaya membuat wajib pajak secara sukarela membayar pajaknya terutama para wajib pajak pengusaha. Hal ini, disebabkan semakin banyaknya pengusaha memperoleh penghasilan maka akan semakin banyak fasilitas pajak yang dapat dipergunakannya. Terjadinya kehilangan potensial akibat pemberlakuan kebijakan penghapusan fiskal juga dapat diatasi.Untuk menghadapi kemungkinan tersebut, pemerintah telah mengantisipasi dan diimbangi dengan adanya penerimaan pajak yang berasal dari meningkatnya kepemilikan NPWP.Pembayaran pajak dapat diketahui dan dikejar dari setiap SPT yang disampaikan oleh WP yang memiliki NPWP.Oleh Karena dalam UU PPh terbaru, pemerintah melalui Dirjen Pajak berupaya menjaring wajib pajak agar semakin banyak memiliki NPWP. (Nasution \& Rudi, 2014; Cahyadi \& Abdul, 2015).

Selain mewajibkan masyarakat sebagai wajib pajak untuk memiliki nomor pokok wajib pajak (NPWP), pemerintah juga perlu meningkatkan penegakkan hukum lain. Penegakkan hukum ini salah satunya dapat berupa pemeriksaan dan penagihan.Sistem pemeriksaan harus dapat mendorong kebenaran dan kelengkapan pelaporan penghasilan, penyerahan, pemotongan dan pemungutan serta penyetoran pajak oleh WP (Sadhani dalam Sukirman, 2011.

Pemeriksaan pajak dilakukan untuk memberi efek jera terhadap wajib pajak nakal sehingga tidak mengulang perbuatan yang sama dimasa depannya. Hal ini yang menyebabkan perlunya dilakukan pembinaan serta pengawasan yang berkesinambungan terhadap wajib pajak.Selain itu sering kali juga wajib pajak dengan sengaja mencurangi pembayaran pajak yang seharusnya dilakukan, oleh sebab itu untuk menguji kepatuhannya perlu pula dilakukan pemeriksaan. Walaupun pemungutan pajak menganut sistem self assessment akan tetapi dalam 6 rangka pembinaan, penelitian dan pengawasan terhadap pelaksanaan kewajiban perpajakan wajib pajak, 
Direktorat Jenderal Pajak masih dapat mengeluarkan ketetapan pajak. Ketetapan pajak ini merupakan komponen official assessment.Surat Ketetapan Pajak ini adalah produk hukum yang dihasilkan sehubungan pemeriksaan pajak yang berisi penjelasan tentang dasar-dasar koreksi pajak serta besarnya sanksi serta pajak yang terutang. Adapun pemeriksaan pajak ini dilakukan oleh Direktorat Jenderal Pajak melalui unit pelaksana yaitu fungsional pemeriksa pajak baik yang berada di kantor pelayanan, kantor wilayah, maupun kantor pusat. Titik tolak penelitian maupun pemeriksaan pajak adalah pemberitahuan pajak yang dilakukan sendiri oleh wajib pajak dalam Surat Pemberitahuan Pajak.Surat Pemberitahuan Pajak ini disampaikan wajib pajak pada setiap akhir tahun pajak. Pada saat penerimaan SPT Tahunan ini petugas pajak akan melakukan penelitian kelengkapan formal dan penulisan pada kolomkolom yang terdapat pada SPT tersebut. Apabila SPT yang disampaikan telah lengkap maka akan diberikan tanda terima SPT Tahunan kepada wajib pajak dan selanjutnya SPT akan direkam, namun apabila SPT belum lengkap dan/atau terdapat kesalahan dalam penulisan maka SPT akan dikembalikan kepada wajib pajak untuk dilengkapi dan/atau diperbaiki (Purba, 2012:2).

Pada tahun 2016 melalui Direktorat Jederal Pajak mengeluarkan kebijakan berupa Tax Amnesty yang merupakan bentuk perkembangan dari kebijakan sunset policy.Amnesti pajak adalah program pengampunan yang diberikan oleh Pemerintah kepada Wajib Pajak meliputi penghapusan pajak yang seharusnya terutang, penghapusan sanksi administrasi perpajakan, serta penghapusan sanksi pidana di bidang perpajakan atas harta yang diperoleh pada tahun 2015 dan sebelumnya yang belum dilaporkan dalam SPT, dengan cara melunasi seluruh tunggakan pajak yang dimiliki dan membayar uang tebusan. Kebijakan Amnesti Pajak adalah terobosan kebijakan yang didorong oleh semakin kecilnya kemungkinan untuk menyembunyikan kekayaan di luar wilayah Negara Kesatuan Republik Indonesia karena semakin transparannya sektor keuangan global dan meningkatnya intensitas pertukaran informasi antarnegara. Kebijakan Amnesti Pajak juga tidak akan diberikan secara berkala. Setidaknya, hingga beberapa puluh tahun ke depan, kebijakan Amnesti Pajak tidak akan diberikan lagi. (Efridawati \& Anggreini, 2015; Lindawati \& Lubis, 2016).

Kebijakan Amnesti Pajak, dalam penjelasan umum Undang-Undang Pengampunan Pajak, hendak diikuti dengan kebijakan lain seperti penegakan hukum yang lebih tegas dan penyempurnaan Undang-Undang tentang Ketentuan Umum dan Tata Cara Perpajakan, UndangUndang tentang Pajak Penghasilan, Undang-Undang tentang Pajak Pertambahan Nilai Barang dan Jasa dan Pajak Penjualan atas Barang Mewah, serta kebijakan strategis lain di bidang perpajakan dan perbankan sehingga membuat ketidakpatuhan Wajib Pajak akan tergerus di kemudian hari melalui basis data kuat yang dihasilkan oleh pelaksanaan Undang-Undang ini.

Ikut serta dalam Amnesti Pajak juga membantu Pemerintah mempercepat pertumbuhan dan restrukturisasi ekonomi melalui pengalihan Harta, yang antara lain akan berdampak terhadap peningkatan likuiditas domestik, perbaikan nilai tukar Rupiah, penurunan suku bunga, dan peningkatan investasi; merupakan bagian dari reformasi perpajakan menuju sistem perpajakan yang lebih berkeadilan serta perluasan basis data perpajakan yang lebih valid, komprehensif, dan terintegrasi; dan meningkatkan penerimaan pajak, yang antara lain akan digunakan untuk pembiayaan pembangunan.

Selain pemeriksaan pajak, ada juga kebijakan yang dilakukan dalam usaha untuk mengoptimalkan penerimaan pajak yaitu dengan melakukan penagihan pajak secara lebih aktif kepda setiap wajib pajak yang menunggak pembayaran pajaknya (Ginting, 2006:12).Penagihan pajak dilakukan karena masih banyaknya wajib pajak terdaftar yang tidak melunasi hutang pajaknya sehingga diperlukan 8 tindakan penagihan yang mempunyai kekuatan hukum yang bersifat mengikat dan memaksa. Maka dengan persetujuan Dewan Perwakilan Rakyat, pemerintah mengeluarkan Undang-undang nomor 19 tahun 2000 tentang Penagihan Pajak dengan Surat Paksa. Menurut Undang-undang nomor 19 tahun 2000 yang dimaksud dengan penagihan pajak adalah:

Penagihan pajak adalah serangkaian tindakan agar penanggung pajak melunasi utang pajak dan biaya penagihan pajak dengan menegur atau memperingatkan, melaksanakan penagihan seketika dan sekaligus, memberitahukan surat paksa, mengusulkan pencegahan, melaksanakan penyitaan, melaksanakan penyanderaan dan menjual barang yang telah disita. Oleh karena itu 
dengan dikeluarkannya Undang-undang tentang penagihan pajak tersebut diharapkan kegiatan penagihan pajak dapat dilaksanakan sebagaimana mestinya karena telah terlihat jelas bahwa tujuan dibuatnya Undang-undang tersebut adalah sebagai landasan hukum bagi fiskus untuk melakukan penagihan kepada wajib pajak yang mempunyai tunggakan pajak sehingga wajib pajak pun termotivasi untuk membayar yang selanjutnya diharapkan dapat meningkatkan penerimaan pajak.

Adelina Simanungkalit,dkk (2015) melakukan penelitian dengan judul “Pengaruh Kewajiban kepemilikan Nomor Pokok Wajib Pajak, Pemeriksaan Pajak dan Penagihan Pajak atas Penerimaan Pajak di KPP Pratama Bitung"dengan hasil penelitian menunjukkan bahwa kewajiban Nomor Identifikasi Kepemilikan Wajib Pajak dan penagihan Pajak tidak mempengaruhi pendapatan pajak, sedangkan variabel pemeriksaan pajak terbukti memiliki efek positif yang signifikan terhadap penerimaan pajak.

Irna Febriyanti (2013) melakukan penelitian yang berjudul "Pengaruh Kewajiban Kepemilikan NPWP, Pemeriksaan Pajak dan Penagihan Pajak terhadap Penerimaan Pajak pada Kantor Pelayanan Pajak Pratama di Wilayah Jakarta Selatan" dengan hasil penelitian menunjukkan bahwa kewajiban kepemilikan NPWP, pemeriksaan pajak dan penagihan pajak terbukti berpengaruh positif terhadap penerimaan pajak. Variabel yang mempunyai pengaruh paling signifikan terhadap penerimaan pajak adalah penagihan pajak dengan nilai beta yang paling besar diantara variabel independen lainnya yakni sebesar $(0,305)$

Dan pada penelitian yang dilakukan oleh Primerdo (2015) yang berjudul "Pengaruh pemeriksaan pajak dan penagihan pajak terhadap efektivitas penerimaan pajak pada KPP Pratama Surakarta", menunjukkan hal yang sedikit berbeda, variabel pemeriksaan pajak tidak berpengaruh secara signifikan terhadap penerimaan pajak. Pemeriksaan pajak berpengaruh signifikan negative terhadap efektivitas penerimaan pajak di KPP Pratama Surakata, menunjukkan bahwa penerapan Self Assesment System berjalan cukup baik.

Perumusan masalah pada penelitian ini adalah:

1. Apakah kewajiban kepemilikan nomor pokok wajib pajak (NPWP), berpengaruh terhadap penerimaan pajak pada Kantor Pelayanan Pajak Pratama Bangkinang?

2. Apakah pemeriksaan pajak berpengaruh terhadap penerimaanpajak pada Kantor Pelayanan Pajak Pratama Bangkinang?

3. Apakah penagihan pajak berpengaruh terhadap penerimaan pajak pada Kantor Pelayanan Pajak Pratama Bangkinang?

4. Apakah kewajiban kepemilikan NPWP, pemeriksaan pajak, dan penagihan pajak secara simultan berpengaruh terhadap penerimaan pajak pada Kantor Pelayanan Pajak Pratama Bangkinang?

Tujuan yang sesuai dengan permasalahan dalam penelitian ini, maka tujuan dari penelitian ini adalah sebagai berikut:

1. Untuk mengetahui adakah pengaruh kewajiban kepemilikan NPWP terhadap penerimaan pajak pada Kantor Pelayanan Pajak Pratama Bangkinang

2. Untuk adakah pengaruh pemeriksaan pajak terhadap penerimaan pajak pada Kantor Pelayanan Pajak Pratama Bangkinang

3. Untuk mengetahui adakah pengaruh penagihan pajak terhadap penerimaan pajak pada Kantor Pelayanan Pajak Pratama Bangkinang

4. Untuk mengetahui apakah kewajiban kepemilikan NPWP, pemeriksaan pajak dan penagihan pajak mempunyai pengaruh secara simultan terhadap penerimaan pajak pada Kantor Pelayanan Pratama Bangkinang.

\section{METODE PENELITIAN}

Penelitian dalam dilakukan pada KPP Pratama di wilayah Bangkinang yang menjadi objek dalam penelitian ini adalah petugas pajak (fiskus) yang berada di KPP Pratama Bangkinang..

Populasi adalah wilayah generalisasi yang terdiri atas objek/subjek yang mempunyai kualitas dan karakteristik tertentu yang ditetapkan oleh peneliti untuk dipelajari dan kemudian ditarik kesimpulannya. Populasi bukan hanya orang, tetapi juga objek dan benda-benda alam yang lain. Populasi juga bukan sekedar jumlah yang ada pada objek/subjek yang dipelajari, tetapi 
meliputi seluruh karakteristik/sifat yang dimiliki oleh subjek/objek itu (Sugiyono, 2009). Populasi dalam penelitian ini adalah Kantor Pelayanan Pajak (KPP) Pratama Bangkinang sebesar 40 orang responden.

Teknik pengambilan sampel pada penelitian ini menggunakan sensus, dengan alasan bahwa melihat jumlah populasi hanya sebesar 40 orang, maka layak untuk diambil semua. Pengambilan sampel yang digunakan adalah metode sensus, Sehingga peneliti merasa perlu untuk meneliti secara keseluruhan tanpa harus mengambil sampel dalam jumlah tertentu (Arikunto,2013)

\section{Sumber data primer}

Data yang dikumpulkan untuk kepentingan penelitian ini, meliputi:

Sumber data primer adalah sumber data yang langsung memberikan data kepada pengumpul data (Sugiyono, 2009). Metode data primer yang digunakan yaitu metode sensus dengan teknik kuesioner (questionnaires). Kuesioner didistribusikan secara personal, sehingga peneliti dapat berhubungan langsung dengan responden dan memberikan penjelasan seperlunya dan kuesioner dapat langsung dikumpulkan setelah selesai dijawab oleh responden. Kuesioner didistribusikan langsung kepada pegawai pajak divisi pelayanan, pemeriksaan, penagihan pada KPP Pratama Bangkinang. Kemudian diolah berdasarkan kriteria yang telah ditentukan.

\section{Sumber data sekunder}

Sumber data sekunder adalah sumber data yang tidak langsung memberikan data kepada pengumpul data (Sugiyono,2009). Data sekunder diperoleh peneliti dari jurnal-jurnal penelitian dan buku-buku yang sesuai dengan penelitian ini

Teknik pengumpulan data pada penelitian ini adalah dengan menggunakan metode angket (kuisioner). Dan skala yang digunakan dalam tingkat pengukuran kuisioner ini adalah skala interval atau sering disebut skala LIKERT yaitu skala yang berisi 5 tingkat prefensi jawaban. Skala likert dikatakan interval karena pernyataan sangat setuju mempunyai tingkat atau prefensi yang "lebih tinggi" dari setuju dan setuju "lebih tinggi" dari ragu-ragu (Ghozali, 2011).

\section{Variabel Independen}

\section{a. Kewajiban kepemilikan NPWP}

Nomor pokok wajib pajak (NPWP) adalah nomor yang diberikan kepada wajib pajak sebagai sarana dalam administrasi perpajakan yang dipergunakan sebagai tanda pengenal diri atau identitas wajib pajak dalam melaksanakan hak dan kewajiban perpajakannya (Mardiasmo, 2009).

\section{b. Pemeriksaan pajak}

Pengertian pemeriksaan pajak adalah menekankan pada pemeriksaan bukti yang berupa buku-buku, dokumen dan catatan yang dilaksanakan secara objektif dan profesional berdasarkan suatu standar pemeriksaan untuk menguji kepatuhan pemenuhan kewajiban perpajakan dan/atau untuk tujuan lain dalam rangka melaksanakan ketentuan peraturan perundang-undangan perpajakan (Pardiat, 2008).

\section{c. Penagihan pajak}

Penagihan pajak adalah proses yang dilakukan DDJP dalam hal memberikan tekanan kepada Wajib Pajak untuk melunasi hutang pajaknya. Tindakan ini dilakukan karena Wajib Pajak tidak mematuhi aspek material peraturan perundang-undangan perpajakan (Rahayu, 2017).

\section{Variabel Dependen}

Penerimaan pajak merupakan sebuah realisasi dari proses pemeriksaan pajak yang optimal. Menurut Waluyo dan Wirawan (2003) dari sudut pandang ekonomi, pajak merupakan penerimaan negara yang digunakan untuk mengarahkan kehidupan masyarakat menuju kesejahteraan. Pajak sebagai motor penggerak kehidupan ekonomi masyarakat. Selanjutnya menurut Inpers RI nomor 5 Tahun 2003 bahwa peran penerimaan perpajakan semakin signifikan dalam pendapatan negara, untuk itu upaya yang sudah dimulai di bidang ini perlu ditingkatkan.

Analisis regresi linear berganda adalah hubungan secara linear antara dua atau lebih variabel independen (X1, X2,...Xn) dengan variabel dependen (Y). Analisis ini untuk memprediksikan nilai dari variabel dependen apabila nilai variabel independen mengalami kenaikan atau penurunan dan untuk mengetahui arah hubungan antara variabel independen dengan variabel dependen apakah masing-masing variabel independen berhubungan positif atau negatif (Priyatno, 2013). 
Berdasarkan hubungan antara variabel kewajiban kepemilikan NPWP pemeriksaan pajak, penagihan pajak dan penerimaan pajak, maka akan digunakan model analisa regresi linier berganda adalah sebagai berikut:

$$
Y=a+b 1 X 1+b 2 X 2+b 3 X 3+e
$$

\section{HASIL DAN PEMBAHASAN}

Hasil dari penelitian ini dapat dilakukan dengan melaksanakan uji asumsi klasik penelitian yang terdiri dari uji normalitas, uji heterokedastisitas, dan uji multikolinieritas. Berikut ini hasil dari uji asumsi klasik:

\section{Uji Normalitas}

Uji normalitas dilakukan dengan tujuan untuk menilai sebaran data suatu data yang terkumpul, apakah data tersebut berdistribusi normal atau tidak. Model regresi yang baik adalah distribusi data normal atau mendekati normal. Pada uji normalitas dilakukan dengan menggunakan Kolmogrov Smirnov (K-S), berikut ini adalah uji normalitas pada penelitian ini:

Tabel 2. Kolmogrov-Sminorv (K-S)

\begin{tabular}{ll}
\hline & $\begin{array}{c}\text { Unstandardiz } \\
\text { Ed Residual }\end{array}$ \\
\hline Kolmogrov-Smirnov Z & .846 \\
Asymp.Sig. (2-tailed) & .471 \\
\hline
\end{tabular}

Sumber : Data Primer (Diolah)

Pada Tabel 2, dapat di hasilkan bahwa pada uji Kolmogrov Sminorv, dapat diketahui yaitu nilai signifikansi yang didapat adalah 0.471 dimana hasilnya menunjukkan tingkat signifikan lebih besar dari $\alpha=0.05$. Hali ini berarti nilai data tersebut terdistribusi normal.

Uji Heterokedastisitas

Uji heteroskedastisitas bertujuan menguji apakah dalam model regresi terjadi ketidaksamaan varians dari residual satu pengamatan ke pengamatan yang lain. Jika varians dari residual satu pengamatan ke pengamatan lain tetap, maka dapat disebut homoskedastisitas dan jika berbeda disebut heteroskedastisitas. Model regresi yang baik adalah yang homoskedastisitas atau tidak terjadi heteroskedastisitas.

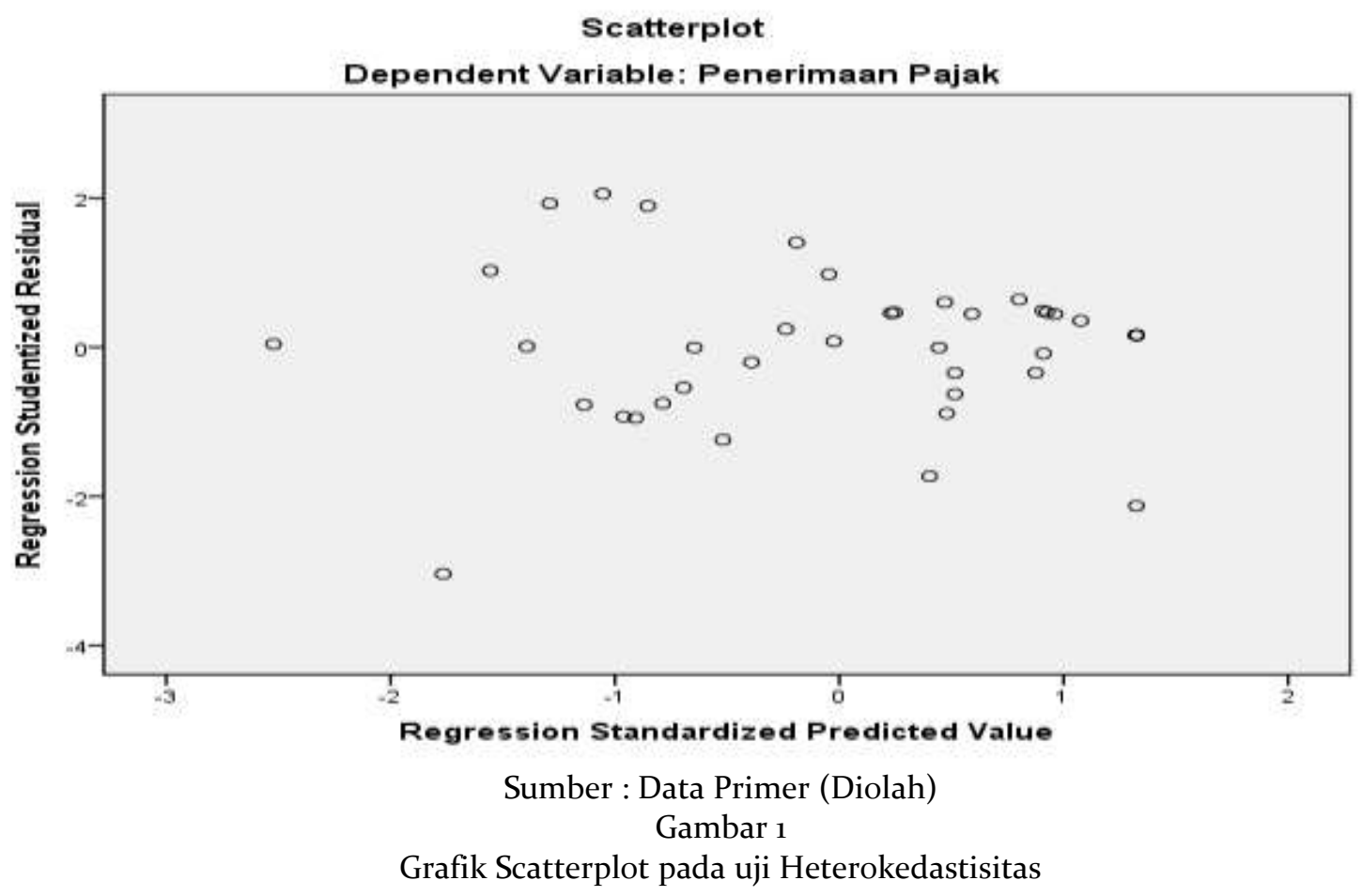


Pada Gambar 1, grafik scatterplot menunjukkan bahwa data tersebar diatas dan dibawah angka 0 (nol) pada sumbu Y dan tidak terdapat suatu pola yang jelas pada penyebaran data tersebut. Hal ini berarti tidak terjadi heteroskedastisitas pada model regresi. Jadi dapat disimpulkan bahwa model regresi penelitian ini layak digunakan untuk memprediksi penerimaan pajak berdasarkan variabel yang mempengaruhinya, yaitu kewajiban kepemilikan NPWP, pemeriksaan pajak dan penagihan pajak.

\section{Uji Multikolinieritas}

Uji multikolonieritas bertujuan untuk menguji apakah model regresi ditemukan adanya korelasi antar variabel bebas (independen). Prasyarat yang harus terpenuhi dalam model regresi adalah tidak adanya multikolonieritas, dengan melihat nilai tolerance dan Variance Inflation Factor (VIF) pada model regresi.

Tabel 3. Uji Multikolinieritas

\begin{tabular}{lll}
\hline & Colinierity Statistic & \\
& Tolerance & VIF \\
\hline Kewajiban Kepemilikan NPWP & 0.537 & 1.863 \\
Pemeriksaan Pajak & 0.346 & 2.889 \\
Penagihan Pajak & 0.514 & 1.947 \\
\hline & Sumber : Data Primer (Diolah) &
\end{tabular}

Pada Gambar 3, hasil perhitungan nilai tolerance menunjukkan tidak ada nilai variabel independen yang memiliki nilai tolerance kurang dari 0,1 yang berarti tidak ada kolerasi antar variabel independen. Hasil perhitungan nilai Variance Inflation Factor (VIF) juga menunjukkan hal yang sama, dengan nilai VIF untuk masing-masing variabel independen kewajiban kepemilikan NPWP 1,863, pemeriksaan pajak 2.889 dan penagihan pajak (PNP) 1.947. Jadi tidak ada variabel independen yang memiliki nilai VIF lebih dari 10.

\section{Analisis Regresi Linier Berganda}

\begin{tabular}{lll} 
& \multicolumn{2}{c}{ Tabel 3. Uji Multikolinieritas } \\
\hline & Unstadaridized Coefficients & \\
& $\mathrm{B}$ & Std.Error \\
\hline (Constant) & 17.888 & 7.596 \\
Kewajiban Kepemilikan NPWP & .088 & .242 \\
Pemeriksaan Pajak & .324 & .239 \\
Penagihan Pajak & .228 & .129 \\
\hline \multicolumn{2}{l}{}
\end{tabular}

Berikut ini persamaan regresi berganda pada penelitian ini adalah:

$\mathrm{Y}=17.888+0.088 \mathrm{X}_{1}+0.324 \mathrm{X}_{2}+0.228 \mathrm{X}_{3}$

Maka interprestasi dari persamaan regresi berganda adalah sebagai berikut :

1. Konstanta $\alpha$ sebesar 17.888 menyatakan bahwa kewajiban NPWP, pemeriksaan pajak, dan penangihan pajak dianggap nol atau tidak ada maka penerimaan pajak sebesar 17.888.

2. Koefisien $b_{1}$ sebesar 0.088 menyatakan bahwa jika terjadinya peningkatan setiap satuan variabel kewajiban NPWP maka penerimaan pajak akan kenaikan sebesar 0.88 .

3. Koefisien $b_{2}$ sebesar 0.324 menyatakan bahwa jika terjadinya peningkatan setiap satuan variabel pemeriksaan pajak maka penerimaan pajak akan mengalami kenaikkan 0.324.

4. Koefisien $b_{3} 0.007$ menyatakan bahwa jika terjadinya peningkatan setiap satuan variabel penagihan pajak maka penerimaan pajak akan mengalami kenaikkan sebesar 0.228

\section{Pengujian Hipotesis}

Pengujian hipotesis secara parsial bertujuan untuk dapat mengetahui ada tidaknya pengaruh antara variabel bebas terhadap variabel terikat yang dilakukan secara sendiri-sendiri, berikut ini hasil pengujian hipotesis secara parsial :

\section{Tabel 4. Uji Parsial}


Masril, Pengaruh Kewajiban Kepemilikan NPWP, Pemeriksaan Pajak Dan Penagihan Pajak Terhadap Penerimaan Pajak Pada Kantor Pelayanan Pajak Pratama Bangkinang

\begin{tabular}{lll}
\hline & Unstadaridized Coefficients & \\
& $\mathrm{t}$ & Sig \\
\hline (Constant) & 2.355 & .024 \\
Kewajiban Kepemilikan NPWP & .362 & .719 \\
Pemeriksaan Pajak & 1.356 & .183 \\
Penagihan Pajak & 1.774 & .085 \\
\hline
\end{tabular}

Sumber : Data Primer (Diolah)

1. Kewajiban NPWP memiliki nilai $t_{\text {hitung }}$ sebesar 0.362 dengan signifikansi sebesar 0.719 sedangkan $t_{\text {tabel }}$ sebesar 1.68830 atau $t_{\text {hitung }}<t_{\text {tabel }}(0.719<1.68830)$ maka dalam pengujian parsial ini kewajiban NPWP tidak berpengaruh terhadap penerimaan pajak pada Kantor Pelayanan Pajak Pratama Bangkinang.

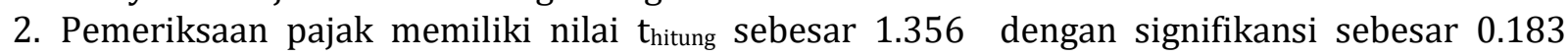
sedangkan $t_{\text {tabel }}$ sebesar 1.68830 atau $t_{\text {hitung }}<t_{\text {tabel }}(1.356<1.68830)$ maka dalam pengujian parsial ini pemeriksaan pajak tidak berpengaruh terhadap penerimaan pajak pada Kantor Pelayanan Pajak Pratama Bangkinang.

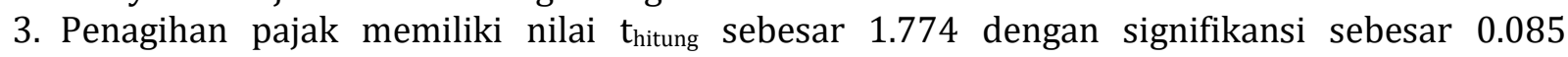
sedangkan $t_{\text {tabel }}$ sebesar 1.68830 atau $t_{\text {hitung }}>t_{\text {tabel }}(1.774>1.68830)$ maka dalam pengujian parsial ini penagihan pajak berpengaruh terhadap penerimaan pajak pada Kantor Pelayanan Pajak Pratama Bangkinang.

Pengujian hipotesis secara simultan bertujuan untuk dapat mengetahui ada tidaknya pengaruh antara variabel bebas terhadap variabel terikat yang dilakukan secara bersama-sama, berikut ini hasil pengujian hipotesis secara parsial :

Tabel 5. Uji Simultan

\begin{tabular}{lll}
\hline & Unstadaridized Coefficients & \\
& $\mathrm{F}$ & $\mathrm{Sig}$ \\
\hline Regression & 7.427 & .001 \\
Residual & & \\
Total & & \\
\hline
\end{tabular}

Sumber : Data Primer (Diolah)

Pada Tabel 5, dengan pengujian hipotesis simultan dapat diketahui bahwa nilai $\mathrm{F}_{\text {hitung }}$ sebesar 7.427 dan nilai $F_{\text {tabel }}$ sebesar 2,80 atau $F_{\text {hitung }}>F_{\text {tabel }}(7.427>280)$ sehingga secara simultan kewajiban NPWP, pemeriksaan pajak dan penagihan pajak berpengaruh terhadap penerimaan pajak pada Kantor Pelayanan Pajak Pratama Bangkinang.

\section{SIMPULAN}

Simpulan pada penelitian ini adalah secara parsial kewajiban NPWP tidak berpengaruh terhadap penerimaan pajak pada Kantor Pelayanan Pajak Pratama Bangkinang yang artinya $\mathrm{t}_{\text {hitung }}$ sebesar 0.362 sedangkan $t_{\text {tabel }} 1.68830$ atau $t_{\text {hitung }}<t_{\text {tabel }}(0.362<1.68830)$, secara parsial pemeriksaan pajak tidak berpengaruh terhadap penerimaan pajak pada Kantor Pelayanan Pajak Pratama Bangkinang yang artinya $t_{\text {hitung }}$ sebesar 1.356 sedangkan $t_{\text {tabel }} 1.68830$ atau $t_{\text {hitung }}<t_{\text {tabel }}$ $(1.356<1.68830)$, secara parsial penagihan pajak berpengaruh terhadap penerimaan pajak pada Kantor Pelayanan Pajak Pratama Bangkinang yang artinya $t_{\text {hitung }}$ sebesar 1.774 sedangkan $t_{\text {tabel }}$ 1.68830 atau $t_{\text {hitung }}>t_{\text {tabel }}(1.774>1.68830)$, dan secara simultan kewajiban NPWP, pemeriksaan pajak, dan penagihan pajak berpengaruh terhadap penerimaan pajak pada Kantor Pelayanan Pajak Pratama Bangkinang yang artinya $t_{\text {hitung }}$ sebesar 7.427 sedangkan $t_{\text {tabel }} 2.80$ atau $t_{\text {hitung }}>t_{\text {tabel }}(7.427$ $>2.80)$.

\section{DAFTAR PUSTAKA}

Cahyadi, B., dan Abdul K., (2015). Peranan Tata Usaha Bagian Umum Kantor Bupati Deli Serdang dalam Meningkatkan Pelayanan, JPPUMA: Jurnal Ilmu Pemerintahan dan Sosial Politik UMA (Journal of Governance and Political UMA), 1 (1): 14-24. 
Dalimunthe, H., \& Br Sihombing, D. (2020). Hubungan Penerimaan Diri dengan Kecenderungan Narsistik pada Mahasiswa Pengguna Instagram di Universitas Medan Area. Journal of Education, Humaniora and Social Sciences (JEHSS), 2(3), 697-703. doi:https://doi.org/10.34007/jehss.v2i3.144

Efridawati dan Anggreini A.L., (2015). Kebijakan Pelayanan Izin Mendirikan Bangunan di Dinas Cipta Karya dan Pertambangan Deli Serdang, JPPUMA: Jurnal Ilmu Pemerintahan dan Sosial Politik UMA (Journal of Governance and Political UMA), 3 (1): 58-70.

Fitriyani, Dewi dan Wiwik Tiswiyanti (2009). Penerapan UU PPh No. 36 Tahun 2008: Manfaat dan Implikasi Bagi Wajib Pajak Pribadi. Jurnal Cakrawala Akuntansi, Vol.1, No.1.

Ghozali, Imam (2011). Aplikasi Analisis Multivariate Dengan Program SPSS. Semarang: Badan Penerbit Universitas Diponegoro.

Hidayat, S. dan Irwan N., (2013). Pelayanan Pencegahan dan Pemadam Kebakaran Pemerintah bagi Masyarakat dalam Mengatasi Musibah Kebakaran, JPPUMA: Jurnal Ilmu Pemerintahan dan Sosial Politik UMA (Journal of Governance and Political UMA), 1 (2): 176-191.

Kadir, A. (2018). Analisis Penetapan Nilai Jual Obyek Pajak Bumi dan Bangunan Sektor Perkebunan sebagai Upaya Peningkatan Sumber Pendapatan Daerah. Journal of Education, Humaniora and Social Sciences (JEHSS). 1 (1): 9-15.

Lindawati dan Lubis, A., (2016). Peranan Kantor Perpustakaan, Arsip dan Dokumentasi dalam Peningkatan Pelayanan bagi Masyarakat, JPPUMA: Jurnal Ilmu Pemerintahan dan Sosial Politik UMA (Journal of Governance and Political UMA), 4 (1): 43-58.

Mardiasmo (2009). Akuntansi Sektor Publik. Yogyakarta: Andi Yogyakarta.

Musnaini, M., \& Wijoyo, H. (2021). Impact of Variety Seeking, dan Elektronic Word of Mouth of Cosmetic Brand Switching Brand Switching di Industri Kosmetik Indonesia. Ekonam: Jurnal Ekonomi, Akuntansi \& Manajemen, 3(1), 23-32.

Nasution, F.R. dan Rudi S.S., (2014). Evaluasi Kinerja Pegawai Kantor Samsat dalam Pelayanan Bea Balik Nama Kendaraan Bermotor, JPPUMA: Jurnal Ilmu Pemerintahan dan Sosial Politik UMA (Journal of Governance and Political UMA), 2 (1): 1-17.

Priyatno Duwi (2013). Mandiri Belajar Analisis Data Dengan SPSS. Mediakom

Rahayu Siti Kurnia (2017). Perpajakan Konsep dan Aspek Formal, Bandung: Rekayasa Sains.

Sugiyono (2009). Metode Penelitian Kuantitatif, Kualitatif dan R\&D, Bandung : Alfabeta.

Suherman, M., Wijoyo, H., \& Indrawan, I. (2020). Industry 4.0 vs Society 5.0.

Tambunan, B. (2016). EFEKTIVITAS PENAGIHAN PAJAK PENGHASILAN PASAL 21 TERHADAP PENERIMAAN PAJAK MELALUI SURAT PAKSA (STUDI KASUS PADA KANTOR PELAYANAN PAJAK PRATAMA (KPP) MEDAN PETISAH). JURNAL AKUNTANSI DAN BISNIS : Jurnal Program Studi Akuntansi, 2(2). doi:https://doi.org/10.31289/jab.v2i2.253

Waluyo dan Wirawan B. Ilyas (2002). Perpajakan Indonesia. Jakarta:Salemba Empat

Wijoyo, H. (2005). Peranan Hukum Pajak Dalam Pembangunan Ekonomi. Jurnal Hukum Respublica, 4(2). Wijoyo, H. (2021). Hukum Bisnis. Insan Cendekia Mandiri.

Wijoyo, H., Akbar, M. F., Safii, A. R., Prasada, D., Yusuf, A., Sudarsono, A., \& Widiyant, W. (2021). The Effect of Tax Stimulus During the Covid-19 Pandemic in Improving the Performance of Taxpayers. Available at SSRN 3873695.

Wijoyo, H., Devi, W. S. G. R., Ariyanto, A., \& Sunarsi, D. (2021). The Role of Regular Tax Functions in the Pandemic Period Covid-19 at Pekanbaru. TIN: Terapan Informatika Nusantara, 1(10), 509-512. 